\title{
Pore Pressure Prediction in Onshore West Niger Delta Using Inverted Seismic Velocity and Derived Velocity (Vp) - Vertical Effective Stress (VES) Coefficients
}

\author{
Umoren, Emmanuel B ${ }^{1} \quad$ Uko, Etim D. $^{2} \quad$ Tamunobereton-ari I. $^{2} \quad$ Israel-Cookey C. $^{2}$ \\ 1.Department of Physics, University of Uyo, Uyo, Nigeria \\ 2.Rivers State University, Port Harcourt, Nigeria
}

\begin{abstract}
In this study, pore pressure has been predicted using seismic data and derived compressional wave velocity $\left(\mathrm{V}_{\mathrm{p}}\right)$ Vertical Effective Stress (VES) coefficients. Post Stack Time Migration (PSTM), angle stack gathers, seismic horizons, checkshot, wireline logs, drilling and pressure data from six wells in the Onshore West Niger Delta, Nigeria were analysed and interpreted. Using generated velocity and density crossplots, the active overpressure generating mechanisms for the studied area were deduced. The $\mathrm{V}_{\mathrm{p}}$-VES coefficients were modelled using the direct pressure data and the overburden profile computed from density log. Post stack seismic inversion was performed to improve the seismic resolution as well as derive acoustic impedance using well velocities and stacking velocities from velocity analysis of the 3-D seismic data. The derived $V_{\mathrm{p}}$-VES coefficients were used to transform the seismic acoustic impedance velocity into seismic pore pressure volume. Pore pressure profiles were accordingly extracted along well paths so as to test the accuracy of the model. Interpreted density-velocity crossplots revealed a decrease in velocity at constant density of $2.4 \mathrm{~g} / \mathrm{cc}$, an indication that unloading mechanisms contribute to overpressure in the field. The Bowers' $\mathrm{V}_{\mathrm{p}}$-VES coefficients of 7.43 and 0.77 were determined for $\mathrm{A}$ and $\mathrm{B}$ parameters respectively. Based on the results obtained, the top of overpressure occurred at a depth of $3750 \mathrm{ft}$ and $3800 \mathrm{ft}$ in UMO-001 and UMO-002 wells respectively with a corresponding average pore pressure gradient of $0.47 \mathrm{psi} / \mathrm{ft}$ for both wells, indicating that the wells are mildly overpressured. Onsets of unloading were observed in UMO-001 and UMO-002 wells at depths of $6250 \mathrm{ft}$ and $6800 \mathrm{ft}$ with pore pressure gradients of $0.51 \mathrm{psi} / \mathrm{ft}$ and $0.60 \mathrm{psi} / \mathrm{ft}$ respectively. The Derived Seismic Pore Pressure (DSPP) matched the measured pressure value (kick) of $5300 \mathrm{psi}$ at a depth of $7450 \mathrm{ft}$ and this validated and further increased confidence on the values of the $\mathrm{V}_{\mathrm{p}}$-VES coefficients derived. These results show that the derived seismic acoustic impedance volume, vertical effective stress and overburden model produce high resolution seismic pore pressure cube in both time and space. The derived models when applied especially, with seismic acoustic impedance volume can be used to plan and drill future wells with great successes in the studied area.
\end{abstract}

Keywords: pore pressure, vertical effective stress, seismic velocity, acoustic impedance

DOI: $10.7176 /$ JEES/9-10-07

Publication date:October $31^{\text {st }} 2019$

\section{Introduction}

Overpressures occur world wide and have been reported frequently by hydrocarbon exploration and production teams across various sedimentary basins. These high pore pressures are known to be responsible for drilling hazards such as stuck pipe, lost circulation, well kicks, borehole instability and blowouts (Narciso et al., 2018). In the Niger Delta basin, these drilling problems have also been encountered and widely reported, hence a good quantitative understanding of formation pore pressure is required for successful exploration and production ventures. According to Udo (2015), Eaton's method has been widely applied for overpressure prediction in onshore Niger Delta and accurate results are only obtained at depths where undercompaction is the primary mechanism for overpressure generation. This often leads to errors in the predicted results because secondary mechanisms have been found to also contribute to overpressure generation in the Niger Delta basin (Udo, 2018). Uko et al., (2013) predicted that porosity data can be used in the prediction of overpressure in the absence of seismic data. Composite $\log$ were used to obtain the required data by digitizing the logs and deduction using the appropriate relationships. It was observed that porosity decreases with depth.

More so, most of the legacy seismic surveys in the Niger Delta have limited azimuth and spread length, thus making detailed velocity analysis for deep overpressure prediction impracticable due to poor resolution at greater depths. This is even made more complicated by the use of methods based on Normal Compaction Trends (NCT) in transforming the seismic velocity to seismic pore pressure cube. Hence, the need to obtain high-resolution velocity through seismic inversion and convert the resulting acoustic impedance to seismic pore pressure directly using velocity- vertical effective stress model. In this way, uncertainty in seismically derived pore pressure is reduced.

Arising from the foregoing, we have proposed a new Velocity - Vertical Effective Stress (VES) model for transformation of seismically derived acoustic impedance cube into pore pressure cube for accurate pore pressure 
estimation in the Niger Delta basin. This work is based on the Bowers' method (Bowers, 1995) which is an effective stress approach that takes into account more than one mechanism of overpressure generation. In particular, we have derived the Velocity-Vertical Effective Stress( $V_{\mathrm{p}}$-VES) coefficients in Bowers model for the Niger Delta. The fidelity of the model is tested by correlating the seismically derived pore pressure with measured pressure data at well locations. This approach holds the extra advantage of eliminating the additional steps of converting impedance into acoustic velocity and density which is known to introduce more potential uncertainties into pore pressure prediction.

\subsection{Geology of Study Area}

The Niger Delta is situated in the Gulf of Guinea and extends throughout the Niger Delta Province as defined by Klettet al., (1997)with sedimentation patterns that reflect response to basement tectonism. From the Eocene to the present the delta has prograded southwestward forming depobelts (Figure 1) namely Northern Delta, Greater Ughelli, Central Swamp, Coastal Swamp, Shallow Offshore and Deepwater (Knox and Omatsola, 1989) that represent the most active portion of the delta at each stage of its development. These depobelts form one of the largest regressive deltas in the world with an area of some $300,000 \mathrm{~km}^{2}$ (Kulke, 1995), a sediment volume of $500,000 \mathrm{~km}^{3}$ (Hospers, 1965), and a sediment thickness of over $10 \mathrm{~km}$ in the basin depocenter (Kaplan, et al., 1994)

The Tertiary section of the Niger Delta is divided into three formations, representing prograding depositional facies that are distinguished mostly on the basis of sand-shale ratios. The type sections of these formations are described in Short and Stauble (1967); Frankl and Cordy (1967) and Tuttle et al., (1999). These are from top to bottom, the Benin Formation made up of massive continental, fluviatile gravels and sands, up to $2000 \mathrm{~m}$ thick; the Agbada Formation that is characteriesed by interbedded fluviatile, coastal, fluviomarine sands and marine shales measuring up to $5000 \mathrm{~m}$ thick and the Akata Formation that comprise massive, marine shales or clays with stringers of sands and silt with thickness in excess of $5000 \mathrm{~m}$. Together, they form a thick, overall progradational passivemargin wedge.

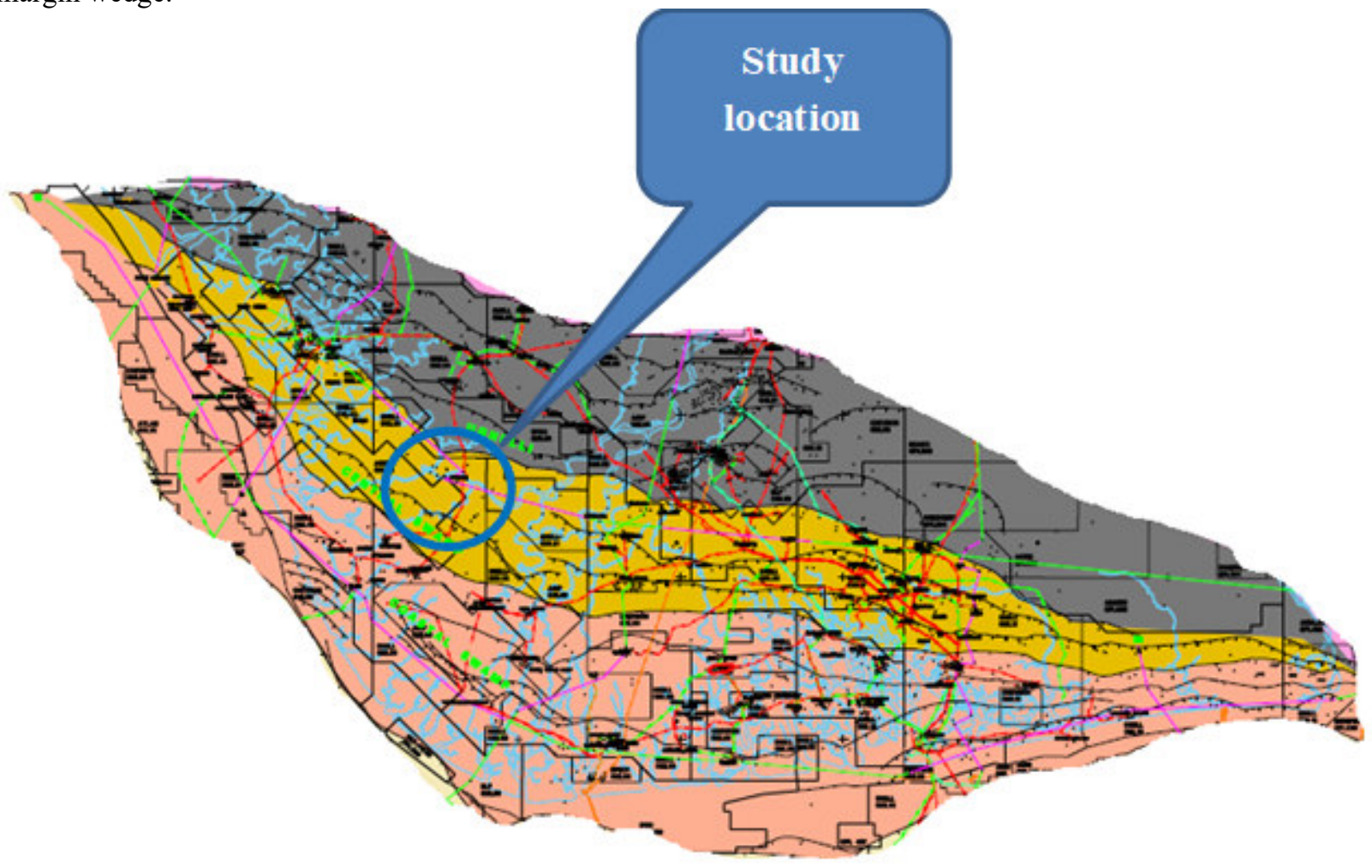

Figure 1 Niger Delta map showing the location of study area

\subsection{METHOLOGY}

3.1 Determination of Vp-VES coefficients

Bowers (2001) relationship between the effective stress and sonic velocity is used.

$$
V_{p}=\nu_{m l}+A \sigma^{B}
$$


where $V_{p}$ is the velocity at a given depth; $\boldsymbol{V}_{\boldsymbol{m} \boldsymbol{l}}$ is the mudline(surface) velocity (normally $5000 \mathrm{ft} / \mathrm{s}$ ); $\boldsymbol{\sigma}$ is the vertical effective stress; and A and $\boldsymbol{B}$ are the Vp - VES coefficients to be determined from calibration with pressure data in a nearby well.

The coefficients, A and B are derived using equation 1 with sonic velocity (Vp from sonic log), VES (computed from measured pressure) and $\mathrm{V}_{\mathrm{ml}}$ as inputs.

By rearranging Equation 1 and substituting in Terzaghi'sEquation $\left(S_{v}=\sigma+P p\right)$, pore pressure is obtained as follows:

$P_{p}=S_{v}-\left(V_{p}-V_{m l} / A\right)^{1 / B}$

To account for the unloading effect, Bowers (1995) empirical relation is used:

$V_{p}=V_{m l}+A\left[\sigma_{\max }\left(\sigma / \sigma_{\text {max }}\right)^{1 / U}\right]^{B}$

where $U$ is unloading parameter and is a measure of the plasticity of the sediments.

Thus pore pressure in unloading case is obtained using Equation 4

$$
P_{p}=S_{v}-\left(V_{p}-V_{m l} / A\right)^{U / B}\left(\sigma_{\text {max }}\right)^{1-U}
$$

\subsection{Seismic Velocity Analysis}

Also, 3-D seismic stacking velocitiesare converted to interval velocities $\left(\mathrm{V}_{\mathrm{int}}\right)$ using Dix Equation:

$V_{\mathrm{int}}=\left[\frac{t_{2} v_{r m s 2}^{2}-t_{1} v_{r m s 1}^{2}}{\left(t_{2}-t_{1}\right)}\right]^{\frac{1}{2}}$

Wheret $t_{2}$ and $\mathrm{Vrms}_{2}$ are the two-way travel time and rms velocity, respectively, in the lower layer and $\mathrm{t}_{1}$ and $\mathrm{Vrms}_{1}$ are the properties in the upper layer

The stacking angle at any given zero-offset two-way travel time ( $\mathrm{t}$ ) and offset $(\mathrm{x})$ is given by:

$$
\operatorname{Sin}^{2} \theta=x^{2} V_{\mathrm{int}^{2}} /\left|V_{r m s^{2}} t^{2}+x^{2}\right|
$$

Where $V_{\mathrm{rms}}$ is the Root Mean Square (RMS)P-wave velocity at time $t$ and Vint is the interval velocity at time, t, (Connolly, 1999).

Seismic velocity data may be provided in the form of stacking velocities $\left(\mathrm{V}_{\mathrm{RMS}}\right)$ as the case here, which need converting to interval velocities $\left(\mathrm{V}_{\text {int }}\right)$ for use in seismic pore pressure prediction. Stacking velocities are picked by seismic interpreters on strong seismic reflections, and can be as far as 500 metres to $1 \mathrm{~km}$ apart horizontally. Each $V_{\text {RMS }}$ value is an average velocity between the seismic reflection pick and the surface. $V_{\text {int }}$ is the velocity between the picked seismic reflections, analogous to a sonic $\log \left(\mathrm{V}_{\mathrm{p}}\right)$ but a much coarser resolution. The $\mathrm{V}_{\text {int }}$ profile maps lateral velocity variation between reflection events. Where $V_{\text {INT }}$ reduces or stays constant with depth it can indicate higher than expected preserved porosity, and perhaps an indication of overpressure.

After the seismic velocity analysis, the derived Vp-VES coefficients are used to transform the derived seismic acoustic impedance velocities into seismic pore pressure.

\subsection{RESULTS AND DISCUSSION}

\section{1. $V_{p}$-VES Coefficients}

With $\mathrm{V}_{\mathrm{ml}}$ taken as $5000 \mathrm{ft} / \mathrm{s}$, VES computed as the difference of overburden and measured pressure values, and $\mathrm{Vp}$ from sonic $\log$, the values of A and B are determined to be 7.43 and 0.77 respectively for the field. The Bowers loading and unloading curves and the determined parameters are shown in Figure 2. 


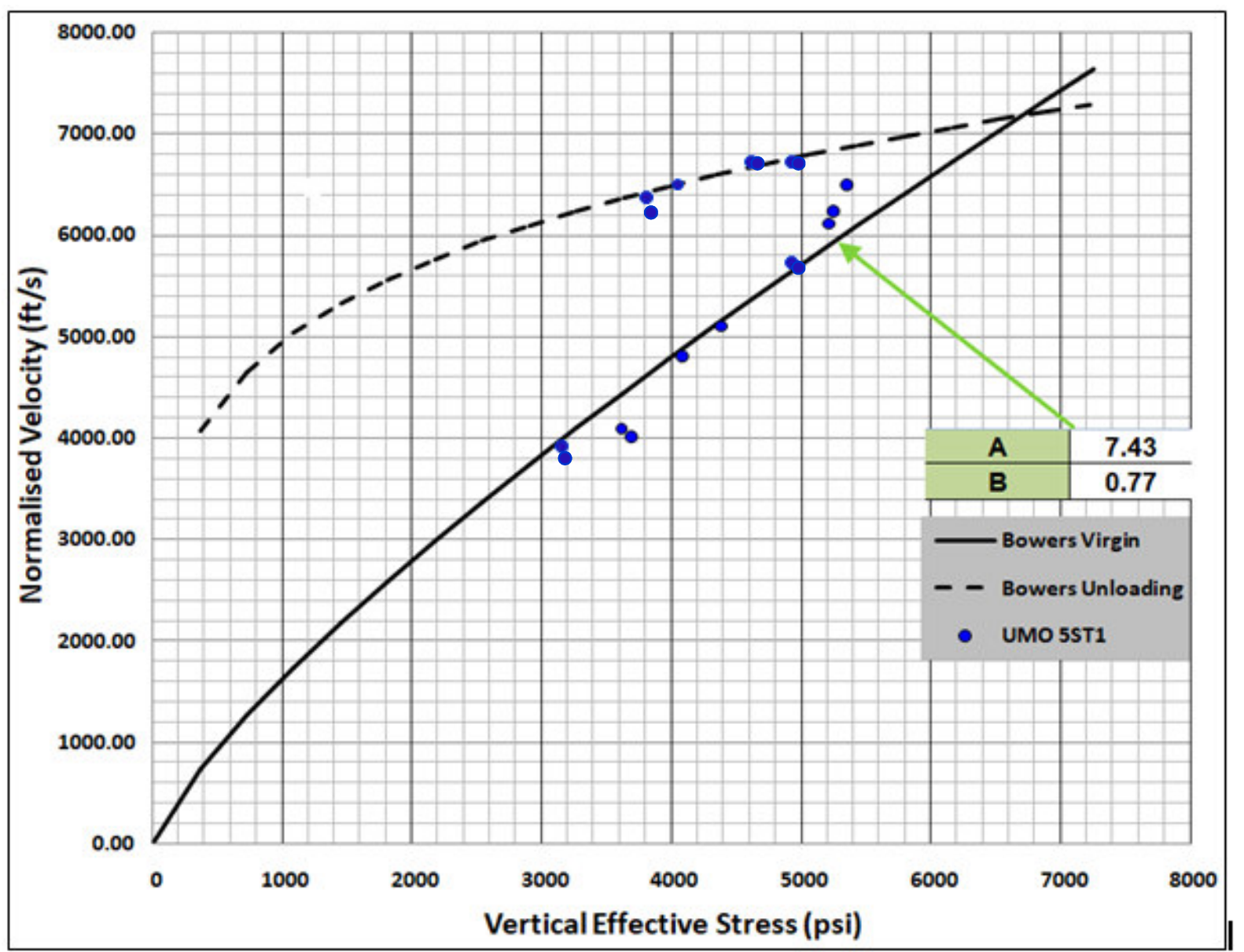

Figure 2: Velocity-Effective Stress Data from UMO_5ST1 wells.

The dashed and thick lines represent loading and unloading curve respectively. The blue data points are $>8,000 \mathrm{ft}$ TVD subsea and aligned with both loading and unloading curves

\subsection{Velocity Analysis}

There are different types of seismic velocities, but only those velocities that are accurate and are close to the propagation velocity of the formation under consideration are suitable for pore pressure prediction. Processing of seismic velocity is to account for the moveout in reflection time with offset. Common processing procedure is to sort the data into common midpoint gathers and determines the best-fit normal moveout velocity $\left(\mathrm{V}_{\mathrm{nmo}}\right)$ as a function of vertical two way time for each major reflector i.e. velocity that flattens the reflector at zero-offset time. Generally, stacking velocities are inadequate for detailed pressure prediction work because of migration velocity that is applied to seismic volumes during processing to improve image quality. Migration velocity is usually a smoothed version of the stacking velocity field that has been adjusted a few percent. This usually results in a highly smoothed velocity field that is designed to operate with migration algorithms that are not designed to handle abrupt changes in the velocity across features like faults, salt bodies and other geological features. Velocity analysis for geopressure prediction is designed to detect such abrupt velocity changes and record them for use in the prediction process. This is the reason why this tedious process of picking the best velocity that flattens the reflector at zero offset must be embarked upon, to ensure the accuracy of the prediction.

Seismic interval velocity realised from Dix equation before post stack inversion appear to be poor in terms of structural and reservoir properties imaging. Clearly, $\mathrm{V}_{\text {rms }}$ input in which velocity picks have been interpolated by repeating each higher value invalidates the Dix formula. If this is addressed by smoothing, long operators may be required. This could smooth over any low velocities thereby hiding fine detail associated with overpressure. It is therefore important that $\mathrm{V}_{\text {rms }}$ input velocities should be appropriately interpolated to avoid erroneous or false seismic interval velocity that is capable of misrepresenting the subsurface.

For instance, the geobodies are conspicuously not visible in Figures $2 \mathrm{a}$ as a result of poor data quality. This was greatly improved both in time and space through the post stack inversion as can be seen in seismic acoustic impedance volume (Figure $2 \mathrm{~b}$ ). The seismic velocity profile extracted along each well that has sonic-velocity shows a reasonable match; evidence that the calibration process was optimal as shown by the seismic-to-well tie in Figure 3. 


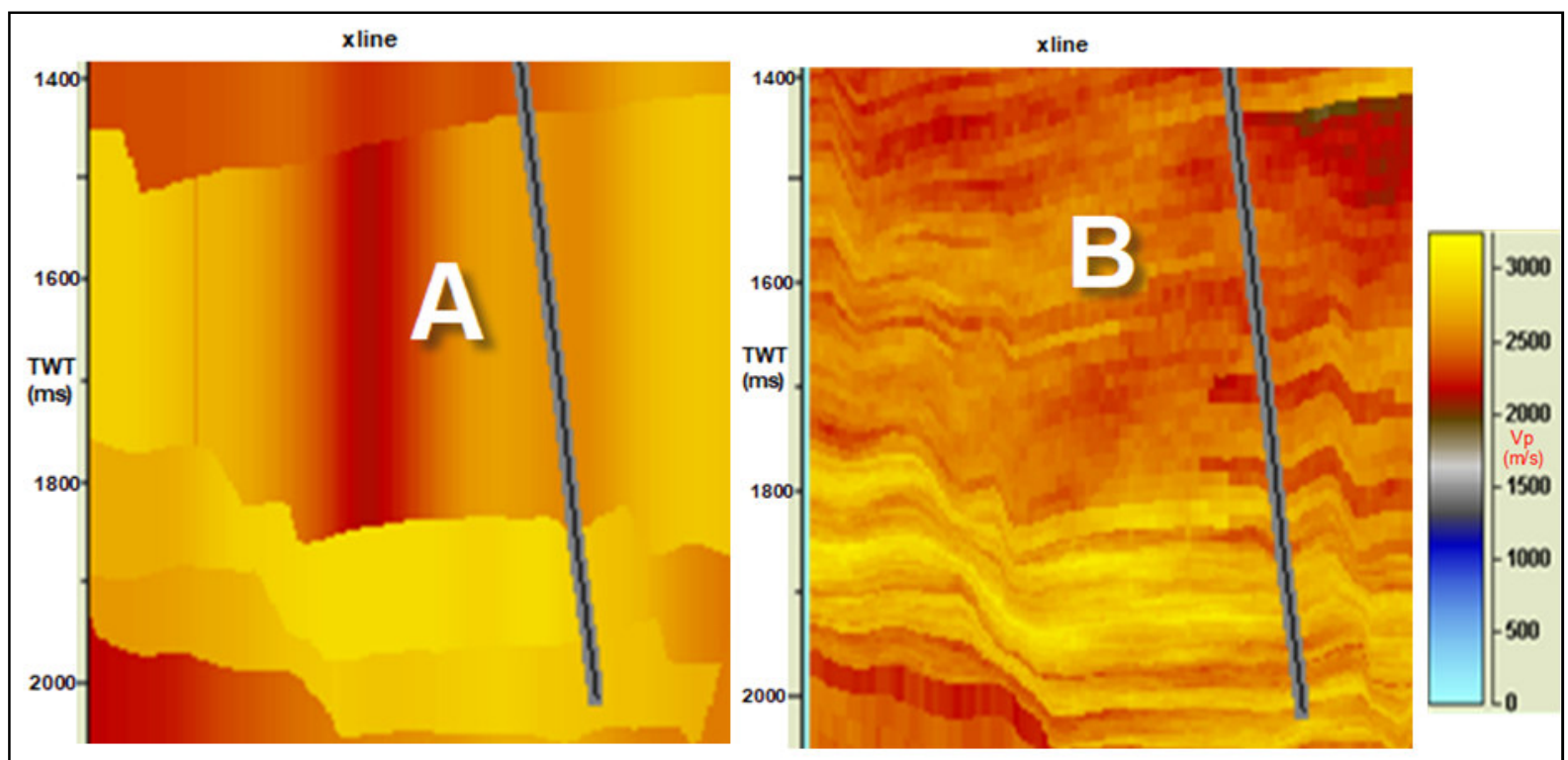

Figure 2: (A) Seismic Interval Velocity before post stack inversion and; (B) Seismic Interval (Acoustic Impedance)velocity (after post stack inversion) with obvious reflection of the geobodies derived from seismicinversion analysis.

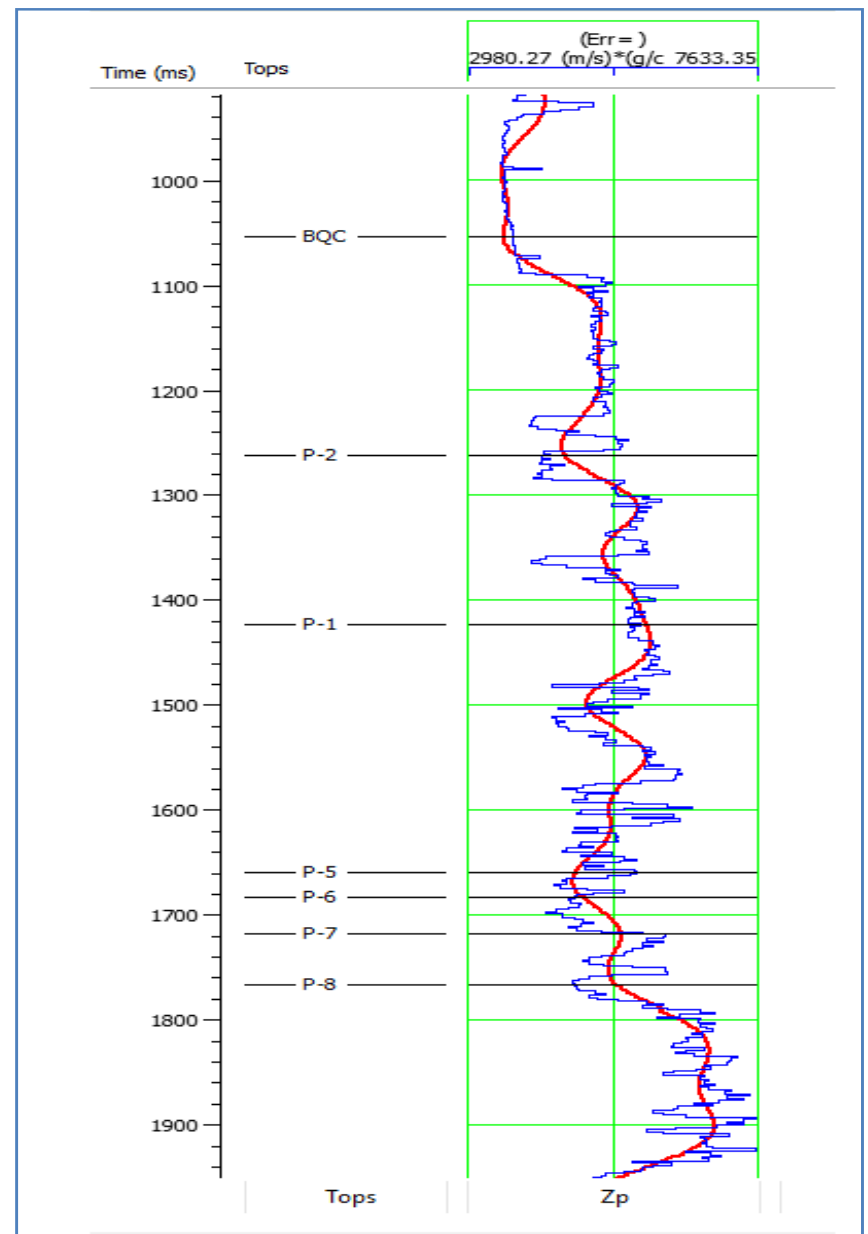

Figure 3: Seismic-to-well tie. The blue is the acoustic Impedance or wavelet $(\mathrm{Zp})$ from well logs while the red is the $\mathrm{Zp}$ from the seismic. There seems to be a match (or correlation). In other words, the seismic -to-well tie is reasonable.

\subsection{Seismically Derived Pore Pressure Prediction}

By combining the VES model obtained in 1D with the calibrated or optimised seismic interval velocity and the 
Acoustic Impedance Vint from seismic inversion obtained from the 3D seismic cube, it was possible to estimate a pore pressure volume for the area of interest. The derived seismic pore pressure and overpressure cubes as shown in Figures 4B and 5B were gotten from the seismic Acoustic Impedance interval velocity and the advantage the post stack inversion workflow is crystal clear when compared to seismic pore pressure and overpressure cubes (Figures 4A and B) gotten without inversion. The pore pressure and the corresponding overpressure values can be easily inferred in time and space in the two seismic pressure cubes in Figures 4B and 5B. The dark red data points are intervals with abnormal pore pressures with formation reaching 4000 psi while overpressure could extend 1000 psi in the field as revealed by the colour code on the legends. This information or interpretation is vital to drillers, exploration and asset team for future well planning and appraisal.

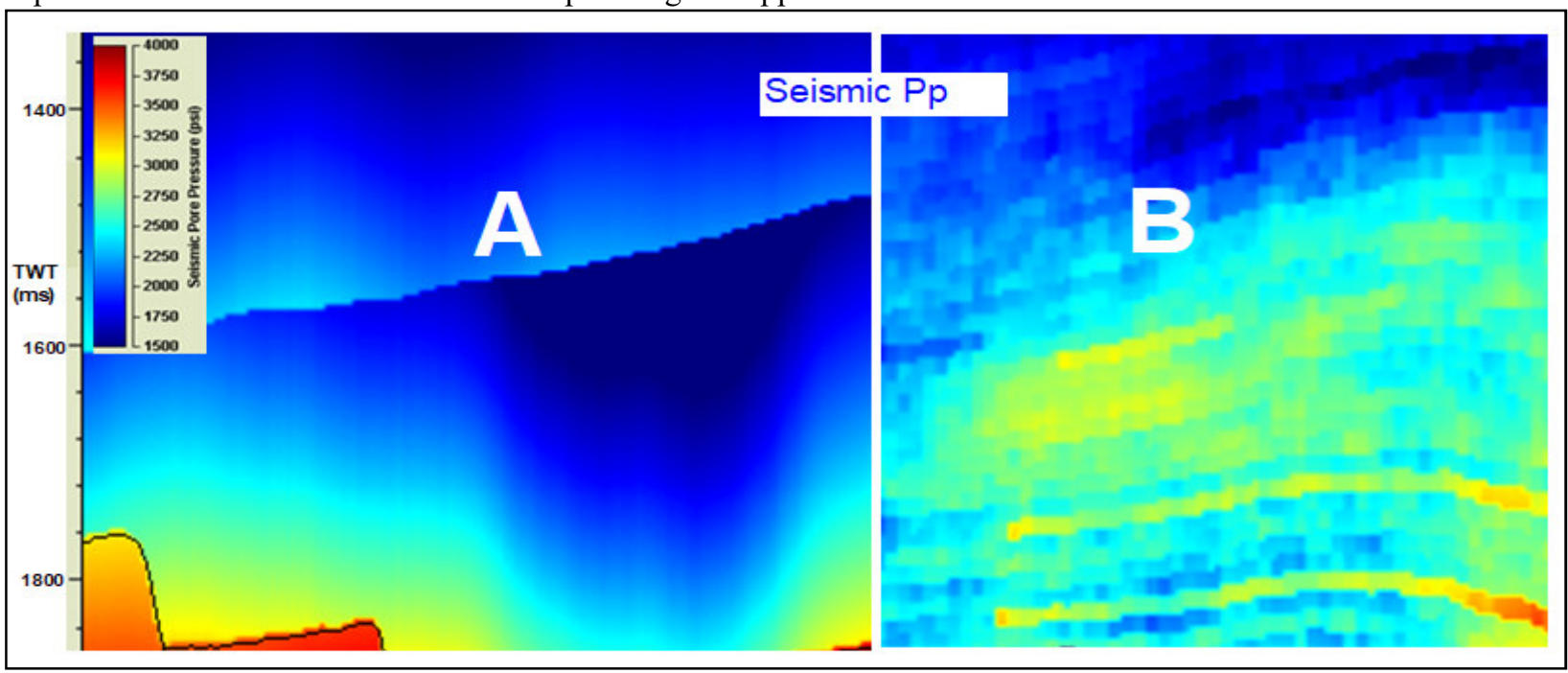

Figure 4: (A) Seismically-derived pore pressure using the optimised seismic Vint. (B) Seismically derived pore pressure using the Acoustic Impedance interval velocity.

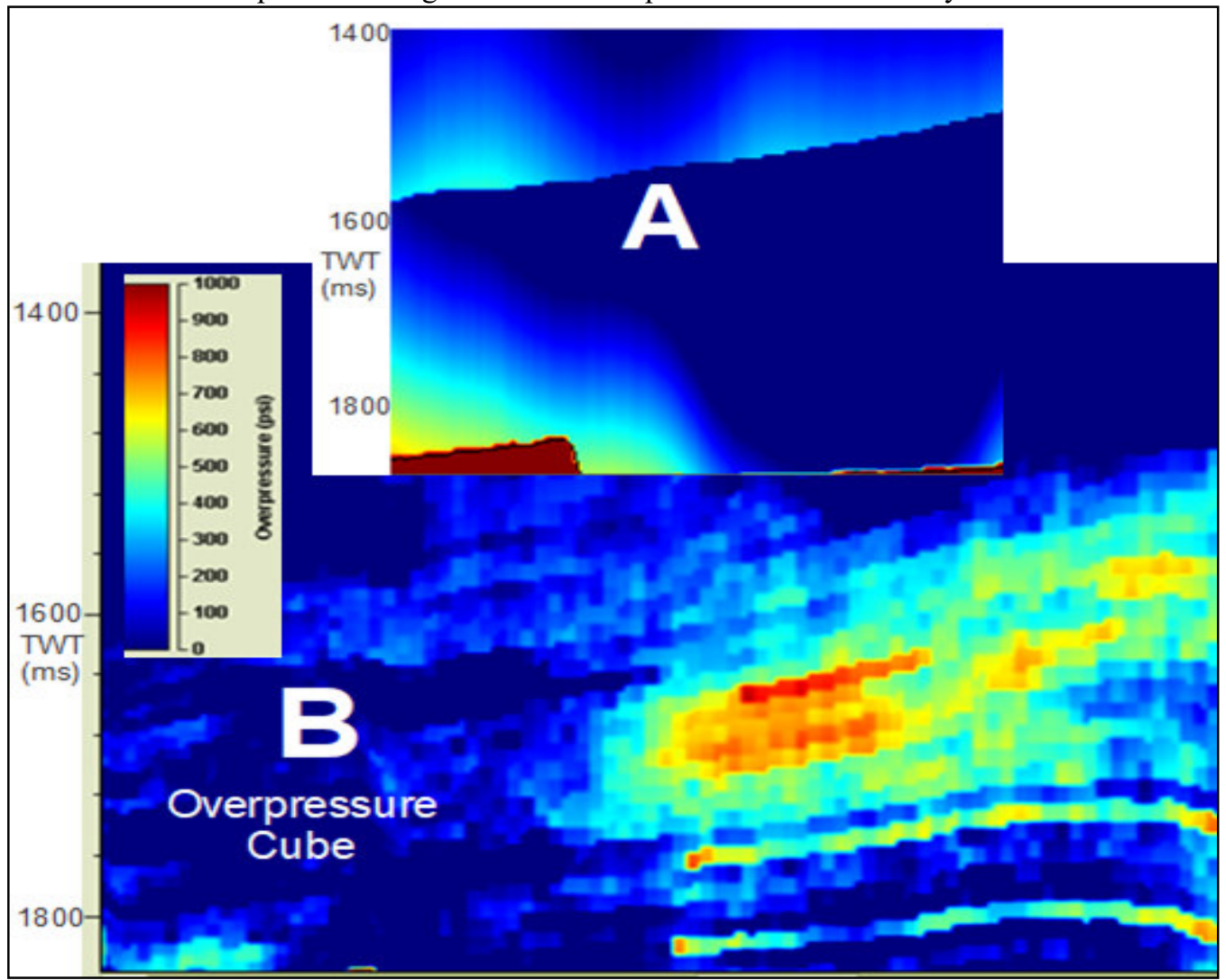

Figure 5: (A)Seismic overpressure volume from the optimised but oversmoothed seismic interval velocityand (B)overpressure volume from the acoustic impedance internal velocity.

As shown in Figure 5A, variation of overpressure could not be imaged as expected, hence the need for seismic 
inversion resulting from poor resolution. Figure $5 \mathrm{~B}$ above shows the overpressure volume derived from the acoustic impedance. The values of the overpressure could range from 600 to $1000 \mathrm{psi}$.

Applying the velocity - pore pressure transform generated from offset sonic velocity; we got a pressure profile which calibrated well with the measured data. This increased our level of confidence in the transform and as such, it could be reliably applied to the proposed deep exploratory well that has no log data. The velocity was also scale on a factor of $+/-5 \%$ of the raw seismic velocity to account for local variation effect in seismic data. Furthermore, the extracted seismic pore pressure profiles along well path approximated the $1 \mathrm{D}$ shale pressure predicted using Bowers VES input parameters as shown in Figures 6 and 7. The kick recorded in UMO-001 well (Figure 6) was an evidence of underbalanced drilling resulting from inaccurate pore pressure prediction but the seismic pore pressure profile (pink trend) can be seen to match the kick. The response or reflection of the derived seismic pore pressure profile (cyan) from the optimised over-smoothed cube seems to ignore subsurface overpressure details in UMO-002 well in Figure 7. The error of over-smoothing in the seismic field mentioned above has been introduced to the seismic pore pressure. In otherwords, error in velocity profile can lead to error in estimated seismic pore pressure.

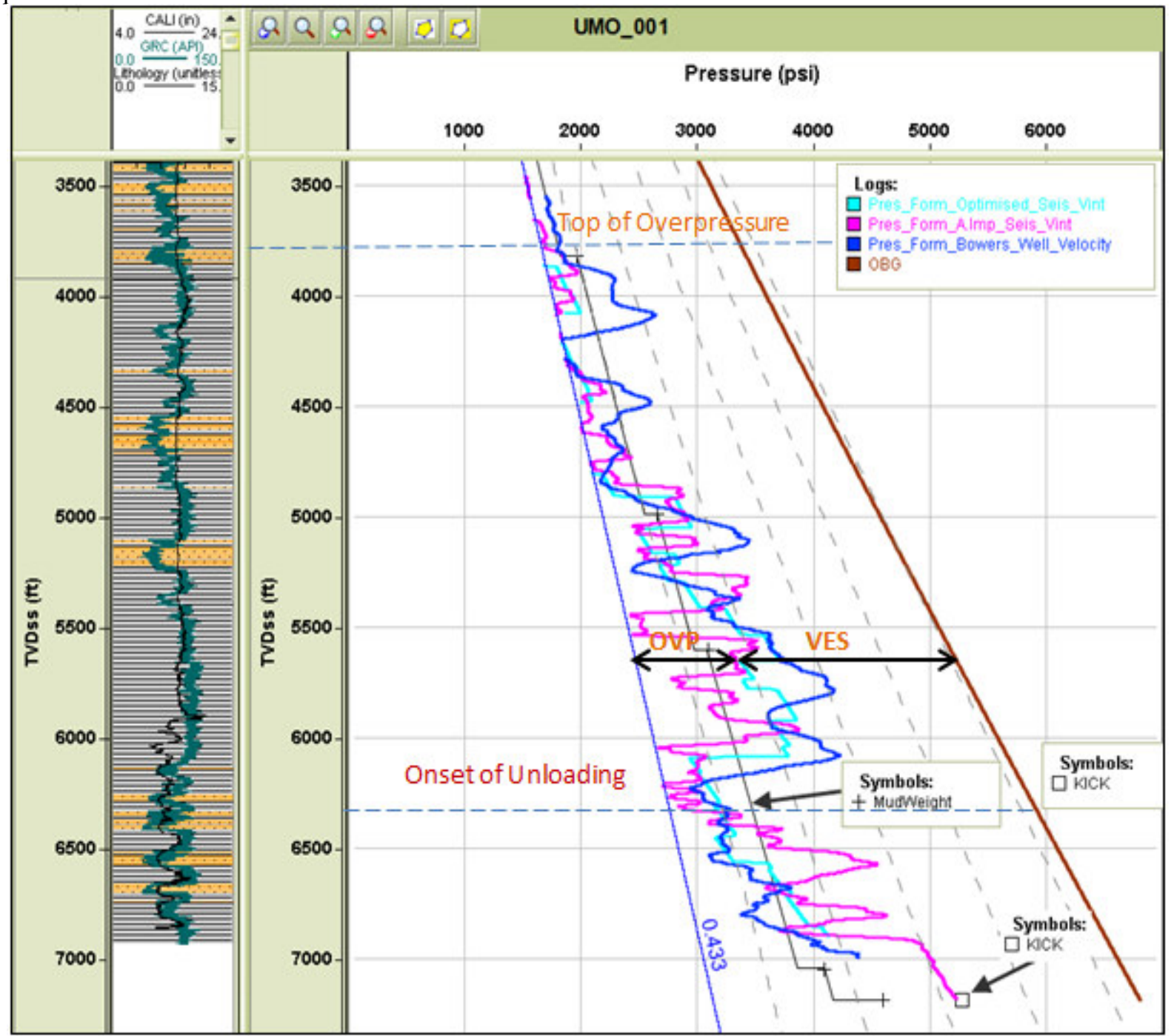

Figure 6: Seismically-derived pore pressure extracted along well path (UMO_1) and compared with the 1D shale pressure predicted using Bowers and well velocity.

The pressure profiles obtained from Bowers model, direct seismic and acoustic impedance are juxtaposed in Figure 8 . The seismically derived pore pressure from acoustic impedance (pink) approximated the kick and this gives credence to the model used. 


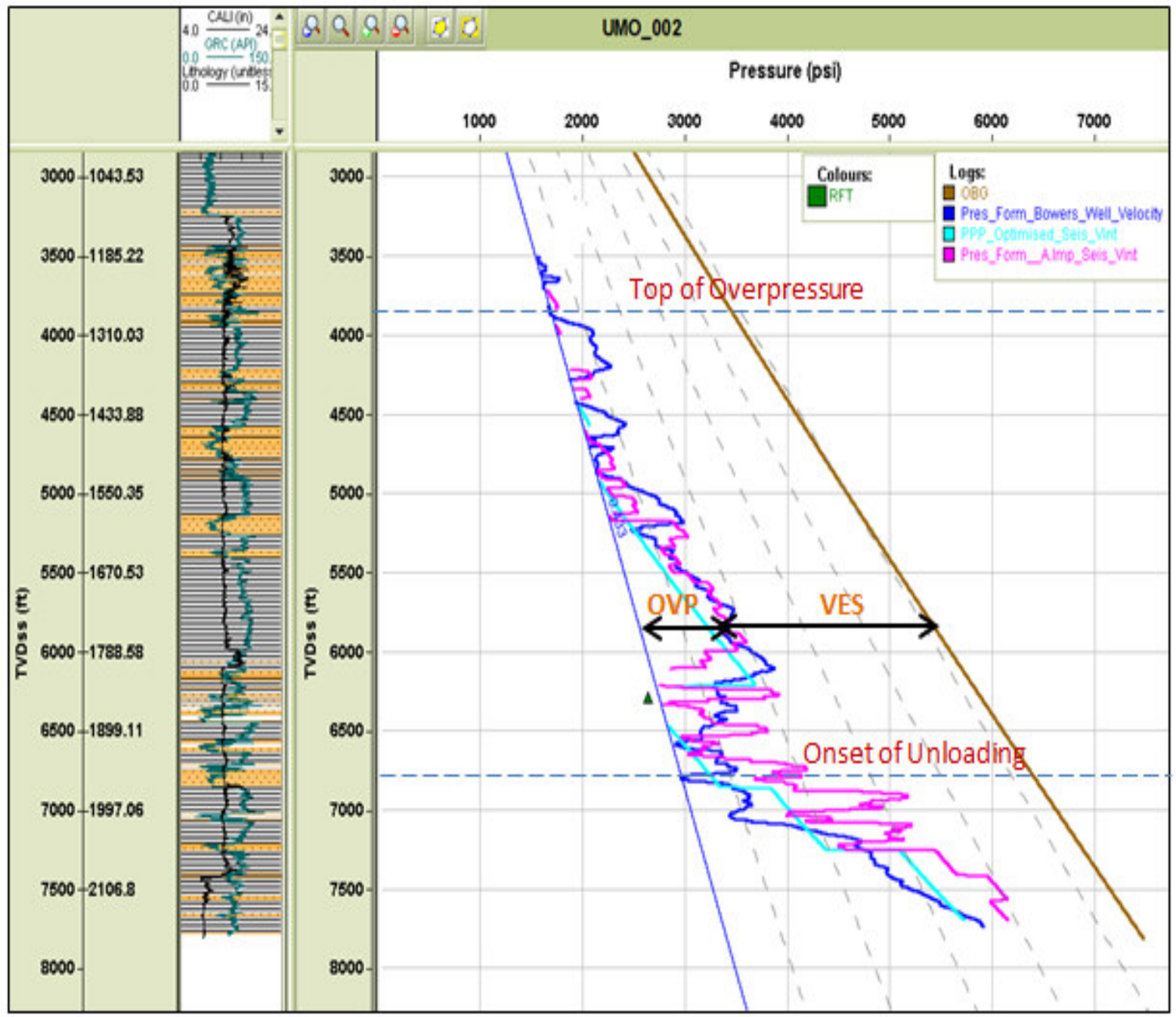

Figure 7: Seismically-derived pore pressure extracted along well path (UMO_2) and compared with the 1D shale pressure predicted using Bowers and well velocity.

Seismic velocity analysis for pore pressure prediction and calibration with well data makes it possible for the predicted pressure from seismic data to compare favourably with the measured pressure for the offset wells. This strengthens the assurance that seismic can be relied upon to give an accurate prediction of pore pressure. As observed in Figure 6 and 7, the seismic pore pressure from acoustic impedance (pink) approximated the Bowers 1D Shale pressure (blue) while the seismically derived pore pressure from optimized interval velocity (cyan) appears incoherent

\section{CONCLUSION}

This study has validated the direct use or plug-in of effective stress coefficients deduced from direct pressure measurements and overburden model derived from density logs in seismic pore pressure transform. It further demonstrated that seismic inversion cube would better reveal geobodies clearly and improved subsurface pore pressure prediction in the deeper overpressure shales intervals. The Niger Delta basin is known for itsmassive shales, with evidence of abnormal pressure at greater depth especially, when approaching the Akata Shale. In such scenarios, 3D seismic images poorly acquired or processed will be insufficient to discriminate individual reservoir horizons and estimate overpressure accurately irrespective of the efforts one would put into the velocity calibration process.Therefore, dedication to well and seismic data conditioning will help optimise signal-to-noise ratio and enhanced accuracy and stability of results.

Further, the use of velocity-vertical effective stress relationship for pore pressure prediction has been made readily available by this research by providing the effective stress coefficients for loading and unloading for this field.The uniqueness of the derived effective stress coefficients has been proven both in $1 \mathrm{D}$ and $3 \mathrm{D}$ pore pressure prediction in the studied field with a remarkable reduction in uncertainty. These coefficients are however, dependent on lithology, cementation, and even pore geometry and vary with the stress or geopressure regime and depth. Consequently, to account for lithology variation, it is recommended to measure Sonic- $\mathrm{V}_{\mathrm{p}}$ by looking at the 
different stratigraphyand effective pressure in the study area. Secondly, seismic inversion should always be incorporated into the pore pressure workflow for improved seismic pore pressure interpretation both in lateral and depth positioning.In velocity picking, picked intervals should not be too small so that obtained resolution will not be too low for accurate pore pressure calculation as seismic sample resolution is $10 \mathrm{~m}$ to $50 \mathrm{~m}$ contrary to $\sim 60 \mathrm{~cm}$ from sonic logging tool.

\section{REFERENCES}

Aki, K., Richards, P. G. (1980). Quantitative Seismology: Theory and Methods, W. H. Freeman and Co. New York, 1:557.

Bowers, G. L. (1995). Pore-pressure estimation from velocity data: accounting for overpressure mechanisms besides undercompaction. SPE Drilling and Completion, 10, 89-95.

Bowers, G. L. (2001). Determining an appropriate pore pressure estimation strategy, Offshore Technology Conference, Paper OTC 13042. Bowers GL (2002). Detecting high overpressure.The Leading Edge, SEG Publication, 174-177

Burke, K., 1972. Longshore drift, submarine canyons and submarine fans in Development of Niger Delta. American Association of Petroleum Geologists Bulletin56, 1975-1983.

Chopra S, Huffman AR (2006). Velocity determination for pore pressure prediction. The Leading Edge, 23(12), $1502-1515$.

Dix, C. H. (1955). Seismic velocities from surface measurements. Geophysics, 20, 68-66.

Doust, H. \&Omatsola, E. (1990). Niger Delta. In Edwards, J. D. and Santogross, P. A., Divergent / Passive margin Basins. AAPG Memoir. American Association of Petroleum Geologists, Tulsa, OK, 48, 239-248.

Durand, J., 1995. High resolution sequence stratigraphy (genetic stratigraphy) in reservoir sedimentology: examples from the Niger Delta. Nigerian Association of Petroleum Explorationists Bulletin10, 65-73.

Dutta N (2002). Geopressure prediction using seismic data: Current status and the road ahead.Geophysics, 67(6), 2012-2041.

Eaton, B. A. (1972). The Effect of Overburden stress on Geopressure prediction from Well Logs. Journal of Petroleum Technology, 929.

Eaton, BA (1975). The equation for geopressure prediction from well logs.Soc. Petr. Engineers, Paper SPE, 5544.

Ejedawe, J. E., Coker, S. J. L., Lambert-Aikhionbare, D. O., Alofe, K. B. \&Adoh, F. O. (1984). Evolution of oil generative window and oil and gas occurrence in Tertiary Niger Delta Basin. American Association of Petroleum Geologists Bulletin, 68, 1744-1751.

Evamy, B. D., Haremboure, J., Kamerling, P.,Knaap, W. A., Molloy, F. A. \& Rowlands, P. H. (1978). Hydrocarbon Habitat of Tertiary Niger Delta. American Association of Petroleum Geologists Bulletin,62, 277-298.

Fertl, W. H. (1976). Abnormal Formation Pressures. New York City: Elservier Publishing Company.

Gardner, G. H. F., Gardner, L. W., Gregory, A. R. (1974). Formation velocity and density - the diagnostic basis for stratigraphic traps. Geophysics, 39(6), 2085-2095.

Huffman, A. R. (2002). The future of pore pressure prediction using geophysical methods, in Huffman AR and Bowers GL (eds.), Pressure regimes in sedimentary basins and their predictions. AAPG Memoir, 76, 217-233

Kulke, H. (1995). Nigeria. In Kulke, H., ed., Regional Petroleum Geology of the World. Part II: Africa, America, Australia and Artarctica: Berlin, GebruderBorntraeger, 143-172.

Mavko, G., Mukerji, T., \&Dvorkin, J. (1998). The Rock Physics Handbook. Cambridge University Press.

Opara, A. I. (2010). Prospectivity Evaluation of Usso Field, Onshore Niger Delta Basin, using 3-D Seismic and Well Log Data. Petroleum and Coal, 52(4), 308-313.

Opara, A. I., Anyiam, U. O. \&Nduka, A. V. (2011). 3-D Seismic Interpretation and Structural Analysis of Ossu Oilfield, Northern Depobelt, Onshore Niger Delta, Nigeria. The Pacific Journal of Science and Technology, $12(1), 502-508$.

Opara, A. I., Onuoha, K. M., Anowai, C., Onu, N. N., Mbah, R. O. (2013). Geopressure and trap integrity predictions from 3-D seismic data: case study of the Greater UghelliDepobeit, Niger Delta. Oil and Gas Science and Technology - Rev. IFP Energiesnouvelles, 68(2), 383396

Pennebaker, E.S. (1968). Seismic data indicate depth and magnitude of abnormal pressure.World Oil, 166, 73-82.

Pickett, G. R. (1963). Acoustic character logs and their applications information evaluation. Journal of Petroleum Technology, 15, 650-667.

Rasolofosaon, P., \&Tonellot, T. (2011). Method for quantitative evaluation of fluid pressures and detection of overpressures in an underground medium. U.S. Patent 7,974,785

Reijers, T. J. A. (2011). Stratigraphy and Sedimentology of the Niger Delta.Geologos, 17(3), 133-162.

Reijers, T. J. A., Petters, S. W. \&Nwajide, C. S. (1997). The Niger Delta Basin. In Selley, R. C., ed., African Basins: Sedimentary Basins of the World.Elservier, 3, 143-172.

Robertson , J. (2013).Overpressure and lateral drainage in the Palaeogene Strata of the central North sea. Durham 
Theses, Durham University. Available at Durham E-Theses Online: http://etheses.dur.ac.uk/9452/

Sayers, C. M., Woodward, M. J., Bartman, R.C. (2002). Seismic pore-pressure prediction using reflection temography and 4-C seismic data.The Leading Edge,21(2), 188-192.

Short, K. C. \&Stauble, A. J. (1965). Outline of geology of Niger Delta. American Association of Petroleum Geologists Bulletin, 51, 761-779.

Stacher, P. (1995). Present Understanding or Delta Hydrocarbon Habitat. In Oti, M. N. and Postma, G., eds., Geology of Deltas: Rotterdam, A. A. Balkema, p. 257-267.

Stump, B., Flemings. P. B., Finkbeiner T., \&Zoback, M. D. (1998). Pressure differences between overpressure ands and bounding shales of the Eugene Island 300 field (offshore Louisiana, U.S.A.) with implications for fluid flow induced by sediment loading: Presented at Overpressures in Petroleum Exploration Conf.

Tanner, M. T. \&Koehler, F. (1969). Velocity spectra - digital computer derivation and applications of velocity functions. Geophysics, 34, 859-881.

Terzaghi, K. (1943). Theoretical soil mechanics. John Wiley and Sons, Inc.

Traugott, M. (1997). Pore and fracture pressure determination in deepwater. World Oil,218(8), 68-70

Tuttle, M. L. W., Charpentier, R. R. \& Brownfield, M. E. (1999). The Niger Delta Province, Nigeria, Cameroon, Equatorial Guinea, Africa. Open file Report, 99-50-H: United States Geological Survey, Washington, D.C. Pp.44.

Greenberg, M. L. and Castagna, J. P.(1992). Shear wave velocity estimation in porous rocks: Theoretical formulation, preliminary verification and applications. Geophysical Prospecting, 40, 195-209.

Gardner, G.H. F., Gardner, L. W. \& Gregory, A.R. (1974). Formation velocity and density: the diagnostic for stratigraphic traps. Geophysics, 39, 770-780.

Connolly, P.(1999). Elastic impedance. The Leading Edge, April, 438-452.

Weber, K. J. \&Daukoru, E.(1975). Petroleum geology of the Niger Delta. Proceedings of the Ninth World PeProceedings of the Ninth World Petroleum Congress,2, 209-221.

Udo, K.I, Akpan, M.J andAgbasi,O. E. (2015). Estimation of Overpressures in Onshore Niger

Delta Using Wire-line Data.International Journal of Science and Research, Vol 4, Issue 5, pp2780-2784

Udo, K.I (2012). Overpressure and Fracture Gradient Prediction Using Wire-Line Data. M.Sc Thesis, Department of Physics, University of Port Harcourt.

Udo, K.I (2018). Vertical Effective Stress - Velocity Relationship Model for Overpressure Prediction in Onshore Niger Delta. Ph.D Thesis, Department of Physics, University of Uyo.

Uko, E. D., Emudianughe, J. E. and Tamunobereton-ari, I. (2013). Overpressure prediction in The North-West Niger Delta, using porosity Data. IOSR Journal of Applied Geology and Geophysics, 1(3), 42-50

Zhang, J., Standifierd, W. B., Leonard, C. (2008). Casing ultradeep, ultralong salt section in deepwater: a case study for failure diagnosis and risk mitigation in record-deep well. SPE Annual Technical Conference and Exhibitions, Paper SPE, 14273.

Zhang, J. (2011). Pore pressure prediction from well logs, modifications and new approaches. Earth Sci. Rev., 108, 50-63.

Zhang J, Wieseneck, J. (2011). Challenges and Surprises of Abnormal Pore Pressure in the Shale Gas Formations. SPE Annual Technical Conference and Exhibitions. Paper SPE 145964 